\title{
The Speaking Difficulties Encountered by Non-English Students in Language Classroom
}

\author{
Rima Rahmaniah, Asbah, Nurmasitah \\ University of Muhammadiyah Mataram, Indonesia,
}

ARTICLE INFO ABSTRACT

Article history:

Received

Revised

Accepted

\begin{abstract}
This research, entitled "The Difficulties Encountered by Non-English Department Students in Speaking English", was a study at Faculty of Teacher Training and Education Muhammadiyah University of Mataram. It was conducted to investigate difficulties encountered by Non-English Department students in speaking. The participants were 15 students from the second semester of Indonesian Department Muhammadiyah University of Mataram. It also aims to investigate the factors which are face by Non-English department students in Speaking English. This research used descriptive quantitative approach. Based on the data from test the difficulties encountered by second year student of Indonesian department are first was from grammar aspect, there were $80 \%$ of students almost entirely inaccurate expect in stock phrases. Second, fluency aspect, there were $73 \%$ speech is very slow and uneven except, for short or routine sentences. Third, it is pronunciation aspect there were $73 \%$ of students gross error and very heavy accent make understanding difficult require frequent repetition. Fourth is from vocabulary aspect there were $60 \%$ of students their vocabulary limited to basic personal and survival areas. The last it is from comprehension aspect there $55 \%$ of students understands only slow, very simple speech on common social and touristic topics; requires constant repetition and rephrasing.Factors were faced by Non-English department student in speaking English there are two factors, from internal factors and external factors. Internal factors such us they are a quite person, they are hard to learn, difficult to remember vocabulary, difficult to pronounce the word,lack of grammatical mastery, they are lazy to memorize vocabulary, they are lack of confidence and fear of making mistake. From external factors, they are seldom speaking English in the class and their environment is not used English and they prefer to use their mother tongue.
\end{abstract}

\section{Introduction}

English is considered and applied as international language. Since then, it is very popular and has been spoken and learned by almost all people in the world. In Indonesia, English is a very important tool to face the globalization era. More over Indonesia has joined AEC (ASEAN Economic Community). So that, in the application of science obtained from the university should be coupled with the mastery of English. By mastering English language, we can communicate with the world community and increase the science and technology through literature only available in English. In this case, English language learned by people according to purpose is closely related to English for Specific Purpose. As Mackay and Mountford (1978) in Addine (2016: 3) ESP is generally used refer to the teaching of a utilitarian purpose. So the English language is learned to be used in real situations and in accordance with their own expertise or profession. As added by Hutchinson and Waters (1987:6), English becomes the accepted international language of technology and commerce, it creates a new generation of learners.

English for Specific Purpose in Higher education is a compulsory subject. Muhammadiyah university of Mataram also makes English as a compulsory subject for Non-English Department. English in other major or Non-English Department namely English for Specific Purpose. The credits 
load of this course varies from two until three credits, and taken in first or second semester. Therefore mastering English is very important for Non-English department students to receive technological progress and industry, to increase their knowledge or to find out a good job.

Mastering English language means can use or speak English. We can communicate, convey our filling, opinion, and story through speaking. Speaking is a constructing meaning that involves producing, receiving and processing information. Penny Ur (1996: 120) argues people who know a language are referred to as speakers of that language. It means if there a student is good in English, so people will naturally think he or she can speak English well. Mastering speaking is not easy especially for Non-English department students because they difficult to memorize and to pronounce vocabulary, less of confident, like to use mother tongue when talking to their friends and anxious to be laughed by his or her friends.

There are some researches that have been conducted. First Sudjasmara (2013) conducted a research "Difficulties encountered by Non-English Department students" in twenty five students of a college of a nursing in Bandung. Second, Agustin (2016) conducted a research "Difficulties encountered by Non-English Department students". The research was conducted in University of MuhammadiyahPurwokerto.

Based on the explanation above the researcher is interested to investigate the difficulties encountered by Non-English Department students in speaking English particularly in Indonesian major students at Faculty of Teacher Training and Education Muhammadiyah University of Mataram.

\section{Research method}

This research was classified as case study with descriptive quantitative approach. According to Yin in (Dawson R. Hancock and Bob Algozzine,2006:15) case study is conducting an empirical investigation of a contemporary phenomenon within its natural context using multiple sources of evidence The design of this research was descriptive quantitative, where the data presents in numerical and descriptive form.

This research was conducted in Faculty of Teacher Training and Education Muhammadiyah University of Mataram to the second year students of Indonesian Department Students in academic year 2016/2017. The population of this study was from second year student of Indonesian department classified into class A and B. Therefore, total numbers of this research sample were 32 students. The sample used purposive sampling. Purposive sampling is a technique of sampling the source data with certain considerations (Sugiyono, 2014:300)

Test and interview used for collecting data. The researcher measurestudents' speaking by having them speaks simple themes such as their daily activities, describing friends and describing their boarding house. While, interview is the process of obtaining information for the purpose of research, by questioning and face-to-face way between the interviewer and the informant, with or without interview guidelines (Bungin,2011:111). In this study the researcher used unstructured interview. This was free interview in which the researcher did not use interview guidelines of the problem to be asked.

\section{III.Finding and Discussion}

Researcher was the instrument in this research. Researcher played important role in conducting the research because of her position as the main instrument in processing data. Other instruments was used to collect the data were speaking test and interview list. 
A. Results of Speaking Test

\begin{tabular}{|c|c|c|c|c|c|c|c|c|}
\hline \multirow[t]{2}{*}{ No } & \multirow[t]{2}{*}{ Name/subject } & \multicolumn{5}{|c|}{ Assessment } & \multirow[t]{2}{*}{ Total } & \multirow[t]{2}{*}{ Score } \\
\hline & & Grammar & Vocab & fluency & accent & compre & & \\
\hline 1 & AS & 2 & 2 & 2 & 2 & 2 & 10 & 40 \\
\hline 2 & MT & 1 & 2 & 2 & 1 & 1 & 7 & 28 \\
\hline 3 & TN & 2 & 1 & 2 & 2 & 1 & 8 & 32 \\
\hline 4 & WD & 1 & 2 & 2 & 2 & 2 & 9 & 36 \\
\hline 5 & DN & 2 & 1 & 2 & 2 & 1 & 8 & 32 \\
\hline 6 & IS & 1 & 1 & 2 & 2 & 1 & 7 & 28 \\
\hline 7 & ISWTN & 1 & 2 & 2 & 2 & 2 & 8 & 32 \\
\hline 8 & ATN & 1 & 1 & 2 & 2 & 2 & 7 & 28 \\
\hline 9 & NS & 1 & 2 & 2 & 1 & 2 & 8 & 32 \\
\hline 10 & SR & 1 & 2 & 1 & 1 & 1 & 6 & 24 \\
\hline 11 & YDN & 1 & 1 & 2 & 1 & 2 & 7 & 28 \\
\hline 12 & HR & 1 & 1 & 1 & 1 & 2 & 6 & 24 \\
\hline 13 & MSH & 1 & 2 & 2 & 1 & 2 & 8 & 32 \\
\hline 14 & BDRTL & 1 & 2 & 1 & 1 & 2 & 7 & 28 \\
\hline \multirow[t]{5}{*}{15} & YHN & 1 & 2 & 1 & 1 & 2 & 7 & 28 \\
\hline & Total & & & & & & & 340 \\
\hline & $\sum \mathrm{fx}$ & & & & & & & \\
\hline & $\mathrm{N}$ & & & & & & & 15 \\
\hline & Mean & & & & & & & 30 \\
\hline
\end{tabular}

From test result, the researcher found the aspect that difficult by students, first was from grammar aspect, there were $80 \%$ of students almost entirely inaccurate expect in stock phrases. Second, fluency aspect, there were $73 \%$ speech is very slow and uneven except, for short or routine sentences. Third, it is pronunciation aspect there were $73 \%$ of students gross error and very heavy accent make understanding difficult require frequent repetition. Fourth is from vocabulary aspect there were $60 \%$ of students their vocabulary limited to basic personal and survival areas. The last it is from comprehension aspect there $55 \%$ of students understands only slow, very simple speech on common social and touristic topics; requires constant repetition and rephrasing.

\section{B. Results of Interview}

From the interview, the researcher conclude the students are a quite person, they are hard to learn, difficult to remember vocabulary, difficult to pronounce the word, they are lazy to memorize vocabulary, they are lack of confidence and fear of making mistake. Then, they are seldom speaking English in the class and their environment is not used English and they prefer to use their mother tongue

\section{III.Conclusion}

The study was designed by using a case study research to investigate the difficulties encountered by Non-English department students speaking English. The researcher used speaking test and interview to collect the data. The participants of the study were all second year students of Indonesian Department that take English subject which consist of 15 students.

a. The Difficulties Encountered by the Students

Based on the data from test the difficulties encountered by second year student of Indonesian department are first was from grammar aspect, there were $80 \%$ of students almost entirely inaccurate expect in stock phrases. Second, fluency aspect, there were $73 \%$ speech is very slow and uneven except, for short or routine sentences. Third, it is pronunciation aspect there were $73 \%$ of students gross error and very heavy accent make understanding difficult require frequent repetition. Fourth is from vocabulary aspect there were $60 \%$ of students their vocabulary limited to basic personal and survival areas. The last it is from comprehension aspect there $55 \%$ of students understands only slow, very simple speech on common social and touristic topics; requires constant repetition and rephrasing.

b. The factors are face by the students in speaking English.

Factors were faced by Non-English department student in speaking English there are two factors, from internal factors and external factors. 
1. Internal factors such us they are a quite person, they are hard to learn, lack of grammatical mastery, difficult to remember vocabulary, difficult to pronounce the word, they are lazy to memorize vocabulary, they are lack of confidence and fear of making mistake.

2. From external factors, they are seldom speaking English in the class and their environment is not used English and they prefer to use their mother tongue.

\section{References}

1. Alfilail, N. (2015).A Thesis.An analysis of factors that influence students' participation in speaking class.A descriptive study at third semester student of English department in Mataram University in academic year 2015/2016.Unpublished Thesis.FKIP, PendidikanBahasaInggris, UniverstasMataram.

2. Arikunto, S. 2006. MetodologiPenelitian. Yogyakarta: BinaAksara.

3. Bashir Mariam, Muhammad azeem,Ashiq Husain Dogar.(2011).Factor Effecting Students' English Speaking Skills.British Journal of Arts and Social Sciences Vol.2 No.1:

4. Brown, H Douglas. (2001) .Language Assessment. New York : Longman.

5. Bungin,Burhan. (2011).PenelitianKualitatif.Jakarta :Pernada Media Group

6. Dawson R. Hancock \&Algozzine,Bob.(2006).Doing Case Study Research.New York : Teachers College Press.

7. Harmer, Jeremy.(2007).The Practice of English Language Teaching. Edinburg: Longman.

8. Hutchinson \&Waters.(1987).English for Specific Purposes. New York: Cambridge University Press.

9. Huges, Arthur.(2003)Testing for Language Teacher, United Kingdom: Cambridge University Press.

10. MisnurHidayanti.(2015).A Thesis : An Analysis of Speaking Problems Faced By The First Year Students Of English Education Program at FKIP UNRAM. Unpublish Thesis. FKIP, PendidikanBahasaInggris, UniverstasMataram.

11. Nunan,D. (2005).Research Method in Language Learning. New York: Cambridge University press.

12. Riduwan.(2014). PengantarStatistikaSosial. Bandung: Alfabeta.

13. Saopan. (2015). A Thesis.Students' Expectation in Learning Speaking: A Survey Study at Eleventh Grade of MA Al Azziziyah Putra in Academic Year 2014/2015. Unpublish Thesis. FKIP, PendidikanBahasaInggris, UniverstasMataram.

14. Sugiyono.(2015).MetodePenelitianPendidikan.Bandung: Alfabeta

15. Sudjasmara,Bayuning. (2013).A Thesis: Difficulties Encountered By Non English Department Students In Speaking English : Case Study at College Nursing Bandung. Unpublish Thesis. University Indonesian of Education

16. Ur,Penny.(1996).A Course of Language Teaching. New York: Cambridge: University Press

17. Yolanda,Sheila.(2015). A Thesis:The Students Difficulties in Speaking at the Tenth Grade of SMAN 1 Sine In Academic Year 2014/2015. Unpublish Thesis of Muhammadiyah University of Surakarta 